\title{
Cuidado e proteção da vida
}

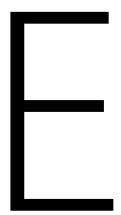

ntre os dias 9 e 12 de agosto, Fortaleza-CE, recebe o $15^{\circ}$ Congresso Brasileiro dos Conselhos de Enfermagem tendo como tema central $\mathrm{O}$ Cuidado e Proteção da Vida e os eixos temáticos: ética e legislação em enfermagem, vulnerabilidade social e determinantes de vida e trabalho. A ideia foi trabalhar as questões do Cuidado e seu significado de Proteção da Vida em consonância com as políticas sociais e econômicas do nosso país e da região em que o congresso será realizado. Para o desenvolvimento desse grande tema foi necessário enfocar as questões da Vulnerabilidade Social que são frequentes devido às desigualdades que temos nas questões de saúde, doença e vida da população brasileira. Em conjunto, os Determinantes

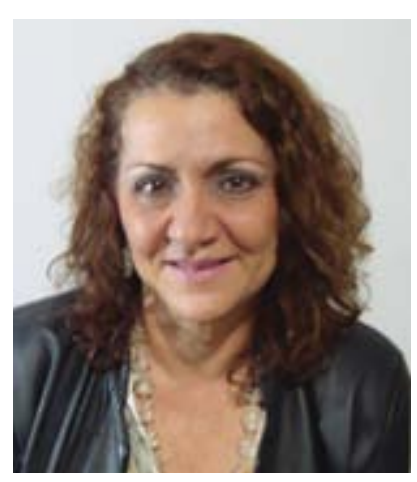
de Vida e Trabalho apontam as possibilidades, na medida de suas reflexões, para um cuidado que de fato possa proteger a vida. E o eixo Ética e Legislação é um dos pilares do Sistema Cofen/Conselhos Regionais. O desenvolvimento do tema e seus subeixos demanda um trabalho de reflexão intenso e que tem sido considerado satisfatório, pois conta com a aprovação da plenária do Cofen.

No tema central, temos uma grande conferência: "Cuidado e Proteção da Vida", que contará com a presença de Frei Betto e de uma enfermeira canadense do Centro de Bioética de Toronto que vai falar sobre o mesmo tema, os demais eixos também contam com apresentações bastante importantes. No total, teremos 17 palestras, cinco mesas-redondas, duas conferências, sete cursos, duas peças teatrais e um painel, entre outras atividades, que são as reuniões do Sistema Cofen/Conselhos Regionais nos mais diversos departamentos. Também foram inscritos 2.840 trabalhos na modalidade Comunicação Coordenada e Pôster.

A Comissão Cientifica, composta por doutores enfermeiros, designados pela presidência do Conselho Federal, tem empregado esforços para que ano a ano o evento tenha um caráter que expresse a cientificidade e o conhecimento que a enfermagem tem construído, bem como se alinhe a um fortalecimento do compromisso do Conselho Federal em relação de expressão qualitativa da profissão na sociedade brasileira. Para este ano está claramente demonstrada uma tendência já sinalizada nos eventos anteriores com uma significativa melhora qualitativa e quantitativa na apresentação dos trabalhos científicos. Concomitante ao $15^{\circ}$ Congresso Brasileiro dos Conselhos de Enfermagem teremos o $9^{\circ}$ CONARENF, Congresso Nacional de Residência em Enfermagem, e o $1^{\circ}$ Encontro Sindical Nacional da Enfermagem. O congresso é planejado e executado por um grupo indicado pela presidência e pelo plenário do Cofen. A Comissão Científica trabalha em conjunto para que o evento alcance o sucesso que a categoria da enfermagem merece.

Dra Maria Ribeiro Lacerda Vice-coordenadora da Comissão Científica do $15^{\circ}$ CBCEnf 